\title{
ELECTRON SPIN RESONANCE DATING OF FOSSIL TEETH: SOME BASIC GUIDELINES TO ENSURE OPTIMAL SAMPLING CONDITIONS
}

\author{
Maïlys RICHARD ${ }^{1}$, Davinia MORENO², Jean-Jacques BAHAIN ${ }^{1}$, Mathieu DUVAL ${ }^{3}$ \\ \& Christophe FALGUÈRES ${ }^{1}$
}

\begin{abstract}
Unlike radiometric methods based on the measurement of radioactive growth or decay of isotopes $\left(\right.$ e.g., ${ }^{14} \mathrm{C},{ }^{40} \mathrm{Ar} /{ }^{39} \mathrm{Ar}$, ${ }^{230} \mathrm{Th} /{ }^{234} \mathrm{U}$ ), the application of radiation exposure dating methods (OSL, TL, ESR) requires the acquisition of data from the sample itself, in addition to those related with its surrounding environment. Indeed, for Electron Spin Resonance (ESR) dating of tooth enamel, the origin of the sample as well as its sedimentary context must be well known to ensure an accurate dose rate reconstruction. The systematic record of sampling data in the field appears to be essential for the implementation of the method and thus the calculation of reliable age results. Consequently, we propose here some basic guidelines to help non-dating specialists intending to collect fossil teeth from archaeological or geological context for subsequent ESR dating purposes.
\end{abstract}

Keywords: ESR dating, tooth enamel, sampling

\section{RÉSUMÉ}

DATATION ESR D'ÉMAIL DENTAIRE : QUELQUES RECOMMANDATIONS POUR UN PRÉLÈVEMENT OPTIMAL

À la différence des méthodes de datation basées sur le phénomène de désintégration radioactive (par exemple ${ }^{14} \mathrm{C},{ }^{40} \mathrm{Ar} /{ }^{39} \mathrm{Ar}$, ${ }^{230} \mathrm{Th}^{234} \mathrm{U}$ ), l'application des méthodes paléodosimétriques (OSL, TL, ESR) requiert l'acquisition de données provenant non seulement de l'échantillon, mais également de son environnement proche. Pour la datation par Résonance de Spin Électronique (ESR) d'émail dentaire, les données relatives à l'échantillon et à son contexte sédimentaire sont indispensables à la reconstruction des débits de dose associés. L'enregistrement systématique des données de terrain concernant l'échantillonnage est donc essentiel pour la mise en œuvre de la méthode et l'obtention d'âges fiables. Cet article, à destination des non-spécialistes, a pour objectif de guider le travail de terrain lors de l'échantillonnage des dents fossiles provenant de contextes archéologiques ou géologiques, à des fins de datation par ESR

Mots-clés : datation ESR, email dentaire, échantillonnage

\section{1 - INTRODUCTION}

ESR dating is a palaeodosimetric method, i.e. based on the quantification of damages produced in the crystal lattice of enamel hydroxyapatite during burial time, as a result of its exposure to natural radioactivity emitted by the sediment and within the sample, as well as cosmic rays. The application of the method to fossil teeth requires the collection of a number of data related to the geological environment of the sample (e.g., site type, sedimentary context, accurate location in the stratigraphic sequence, homogeneity of the sediments, etc.), in addition to those from the sample itself.
In order to guide non-dating specialists aiming to sample teeth for ESR dating purposes, we present hither a short paper with some basic guidelines for field work, along with a sampling form to record field data necessary for an optimal implementation of the ESR dating method.

\section{2 - ESR DATING OF FOSSIL TEETH: BASIC PRINCIPLES}

Electron Spin Resonance can be used to date fossil teeth with an age ranging from around $2 \mathrm{Ma}$ to $30 \mathrm{ka}$ (for details see for example Grün, 1989; Ikeya, 1993). During

\footnotetext{
${ }^{1}$ Département « Homme et Environnement », Muséum National d'Histoire Naturelle, UMR 7194, FR-75013, PARIS.

Email: mailys.richard@mnhn.fr

${ }^{2}$ Centro Nacional de Investigación sobre la Evolución Humana (CENIEH), ES-09002, Burgos.

${ }^{3}$ Australian Research Centre of Human Evolution (ARCHE), Environmental Futures Research Institute, Griffith University,

AU-QLD 4111, Nathan.
} 
the burial of a tooth, the production of radiations from ${ }^{238} \mathrm{U},{ }^{235} \mathrm{U}$ (from the surrounding sediment and within the tooth, which incorporates $U$ during fossilization), ${ }^{232} \mathrm{Th}$ decay chains and ${ }^{40} \mathrm{~K}$ (from the surrounding sediment), as well as cosmic rays damage the hydroxyapatite structure of the tooth enamel (fig. 1). From a physical point of view, it can be expressed by the accumulation of unpaired electrons in defects of the crystalline structure (called "traps") as a function of the absorbed dose of ionizing radiations (alpha, beta, gamma and cosmic) and the exposition time.

The ESR age calculation relies on the determination of two physical quantities: on one hand, the total dose absorbed by the tooth since the burial (in gray, Gy), usually called "equivalent dose" $\left(\mathrm{D}_{\mathrm{E}}\right)$, and on the other hand, the average dose of exposure to alpha, beta, gamma and cosmic radiations during one year (in Gy. $\mathrm{a}^{-1}$ ), usually called "annual dose" or "dose rate" $\left(\mathrm{D}_{\mathrm{a}}\right)$. To keep it simple, an ESR age may be obtained by dividing $\mathrm{D}_{\mathrm{E}}$ by $\mathrm{D}_{\mathrm{a}}$ (further details may be found in Duval, 2015). The $\mathrm{D}_{\mathrm{E}}$ is measured using ESR spectroscopy, by studying the growth of the ESR signal of the enamel sample as a function of the absorbed radiation dose. In contrast, the dose rate is evaluated by measuring the radioactivity in the tooth itself (in all the dental tissues constituting the tooth, i.e. enamel, dentine and, sometimes, cement) and in its surrounding (sediment, rocks, etc.). It is therefore crucial to reconstruct the environment of the tooth to ensure a reliable age calculation, especially when variables such as the dose rate from the sediment represent more than $50 \%$ of the total dose rate (e.g., Richard et al., 2015).

Hereinafter, we provide some recommendations on the tooth sampling strategy to follow for ESR dating, in order to collect suitable samples and to record important data needed for subsequent analyses and dose rates reconstruction.

\section{3 - SAMPLING STRATEGY}

Based on our experience in ESR dating of fossil teeth, we have identified several key criteria regarding sample selection to ensure the implementation of the ESR dating procedure under the best possible conditions:

- herbivorous teeth are usually the most suitable for ESR dating, particularly bovid, hippopotamid and rhinocerontid molars, because the enamel is thick enough ( $\geq 1 \mathrm{~mm}$ ) to ensure a correct cleaning on both sides to remove the external part irradiated by alpha particles and minimise the beta dose contribution. Equid teeth are also appropriate, although it should be taken into account that the porosity of the cement covering the external side of the enamel can lead to some issues regarding U-uptake modelling. If these species are lacking from the faunal assemblage, smaller teeth, from species such as cervid and ovicaprid, can be collected, whereas carnivora teeth are usually not recommended, given their thin enamel layer;

- the selected tooth should preferentially be well preserved, as previous studies show a direct correlation between fractures and diagenetic weaknesses in dental tissues and preferential migration of U-series elements (e.g. Duval et al., 2011);

- the selected tooth has to be in primary depositional position, i.e. it must not have experienced sedimentary reworking. This would indeed precludes an accurate

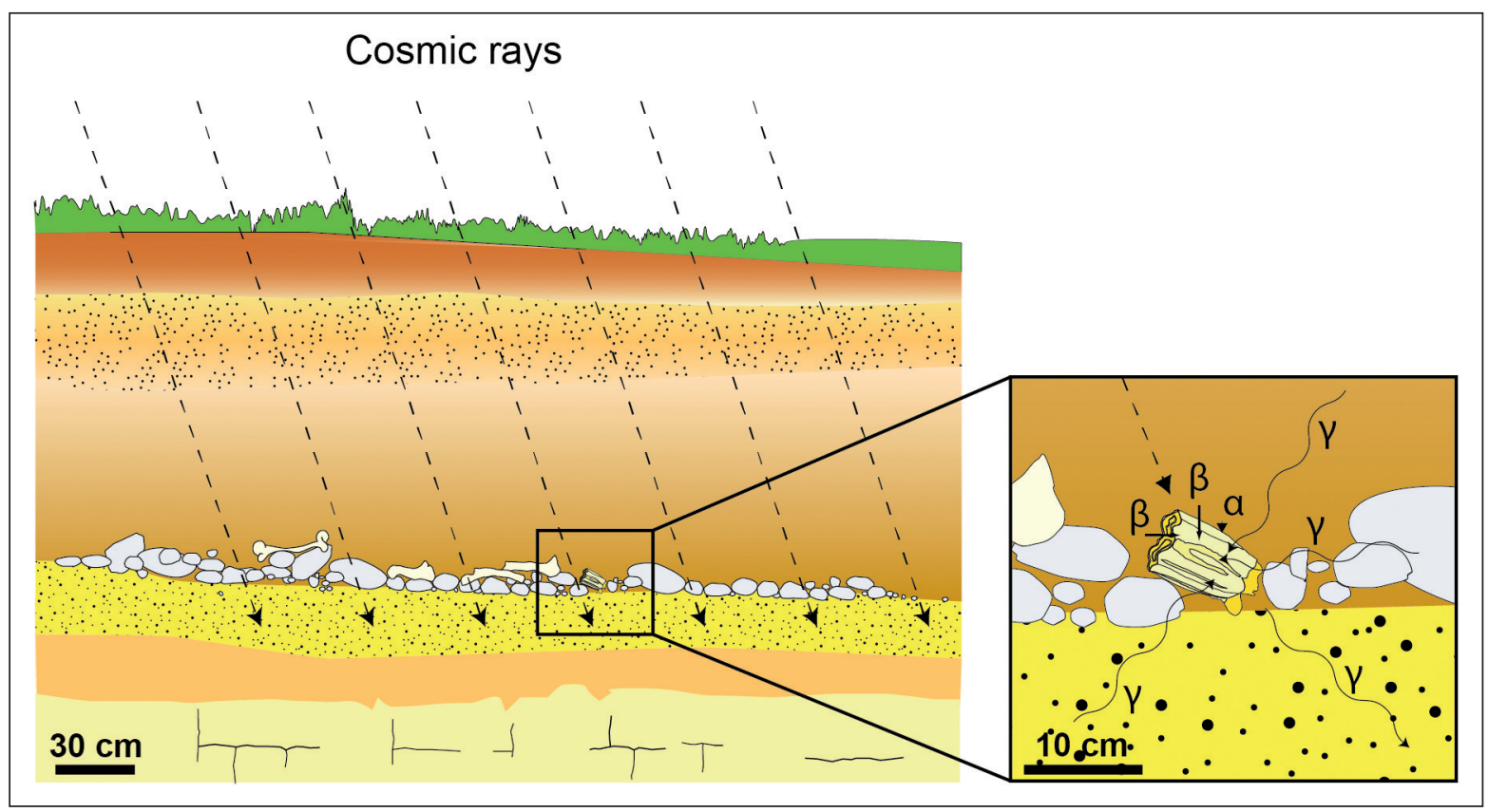

Fig. 1: Schematic representation of alpha, beta and gamma and cosmic rays received by a tooth buried in sedimentary deposits (modified from Despriée et al., 2012).

In a 2.5 density sediment, alpha particles have a range of $20-30 \mu \mathrm{m}$, beta particles of around 2-3 mm and gamma rays up to $30 \mathrm{~cm}$.

Fig. 1 : Représentation schématique des rayonnements alpha, beta, gamma et cosmique reçus par une dent dans des dépôts sédimentaires (modifiée d'après Despriée et al., 2012). Dans un milieu d'une densité de 2,5, les particules $\alpha$ ont un parcours d'environ 20-30 $\mu$ m, les particules $\beta$ d'environ $2-3 \mathrm{~mm}$ et les rayons $\gamma$ jusqu'à $30 \mathrm{~cm}$. 
reconstruction of the dose rate, as it is by definition based on the data collected from the present-day conditions;

- if possible, the sample must be collected with its embedding sediment, from which $\mathrm{U}$, Th and $\mathrm{K}$ contents will be measured in order to evaluate the beta dose rate received by the tooth. If not, sediment has to be collected as closely as possible to the sample position (especially in case of teeth selected from collections). The sediment sample must be wrapped in a plastic bag and sealed with tape to avoid a dry out in order to ensure a correct evaluation of its water content (in weight \%);

- the stratigraphic unit from which the tooth originates should be still preserved and accessible on site to carry out in situ measurement of radioactivity and to derive the external gamma dose rate. If not, the gamma dose can be evaluated from radioelement contents of the sediment collected as indicated above. However, in the case of heterogeneous sedimentary context, it may be useful to estimate radioactivity for overlying and underlying strata and different sedimentological components located in the surrounding of the tooth. Because the reliability of the age result depends on the accuracy of the dose rate reconstruction, the dated tooth and the embedding sediment should preferably be sampled during present-day excavations as closely as possible to a section in which the gamma dose rate could be measured. However, in the case of sites that are no longer excavated, the sample should be selected preferentially according its proximity to the preserved (available) sections.

\section{4 - IMPORTANT CONSIDERATIONS REGARDING DOSE RATE RECONSTRUCTION}

In a 2.5 density sediment, alpha particles have a range of 20-30 $\mu \mathrm{m}$, beta particles, around $2-3 \mathrm{~mm}$ and gamma rays up to $30 \mathrm{~cm}$. The alpha contribution from the sediment or the external tissues in contact with the enamel can be easily suppressed in the laboratory by removing at least $20 \mu \mathrm{m}$ from both sides of the enamel layer. However, external beta and gamma dose rates are very dependent on the sedimentary context of the sample, and have to be determined precisely. If the enamel layer is in direct contact with the sediment on one side, then the beta dose rate has to be calculated from a sediment sample, from which radioactive element contents ( $\mathrm{U}$, Th and $\mathrm{K}$ ) are measured. This may be done using for example high resolution gamma ray spectrometry (HRGS) or inductively coupled plasma-mass spectrometry (ICP-MS). Around $100-150 \mathrm{~g}$ of sediment are usually required for HRGS analyses, whereas only a few grams are needed for ICP-MS analyses. Consequently, we advise that the tooth should be collected with at least $150 \mathrm{~g}$ of its embedding sediment.

The gamma dose rate is generally measured in situ. It can be done either by inserting TL or OSL dosimeters, which will record the gamma dose rate for at least several months, and/or using a portable gamma spectrometer, which can provide rapid dose rate measurements (in 10 to
$30 \mathrm{~min}$ ). Both kinds of measurements should be done at a $30 \mathrm{~cm}$ horizontal depth within the targeted stratigraphical unit, in order to make sure that only the radioactivity of the sediment is recorded. If this horizontal depth is lower than $30 \mathrm{~cm}$, then the true depth should be reported in order to correct the gamma dose rate results accordingly.

By definition, the cosmic rays are attenuated by the rock and sediment covering the tooth. Consequently, the true cosmic dose rate received by the sample decreases according to the thickness of these deposits. In the case of "young" samples (e.g., from Upper Pleistocene deposits), and/or in a very low radioactive context, the contribution of the cosmic dose rate has proven to be significant: for instance, in the case of a cave, the roof thickness and the proximity of the sample from the cave entrance should be recorded and taken into account for cosmic dose rate estimation. Other parameters such as the altitude above sea level and latitude may also affect the intensity of the cosmic rays (see Prescott \& Hutton, 1994). Therefore, it is recommended to report the GPS coordinates of the sampling point.

\section{5 - SAMPLING FORM FOR ESR DATING OF TOOTH ENAMEL}

Fieldwork represents the first step of the ESR dating process. As explained above, it is essential to collect all the basic information relating the tooth to its surrounding environment to ensure the most accurate dose rate estimation. This has been summarised in a form addressed to non-specialists in ESR dating (e.g., archaeologists, geologists, palaeontologists, etc.) working in the field, who may collect fossil teeth for subsequent ESR dating (fig. 2).

First, the position of the tooth must be precisely known. This includes the location of the tooth within the excavation area and its position within the stratigraphic section. For the evaluation of the cosmic dose rate, it is necessary to get an estimation of the thickness of the overlying deposits. Sometimes, the actual situation is not representative of the past history, especially if erosion took place and removed most of the sediment cover. In this case, the maximum sediment thickness above the sample should be estimated as well.

On site, the sediment surrounding the sample must be collected. It is used to derive the beta dose rate and estimate the water content, and sometimes the gamma dose rate if the sedimentary context is homogeneous within a $30 \mathrm{~cm}$ radius sphere around the sampling spot, and/or if in situ measurements cannot be performed. Nevertheless, as far as possible, the gamma dose rate should always be derived from in situ measurements. In this case, the dosimeters and/or the portable gamma spectrometer should be placed in the vicinity of the sample, and the position has to be recorded. Sometimes, fossil teeth are taken from collections and their exact original location spot may no longer exist. Consequently, in situ measurements have to be performed as closely as possible to the tooth 


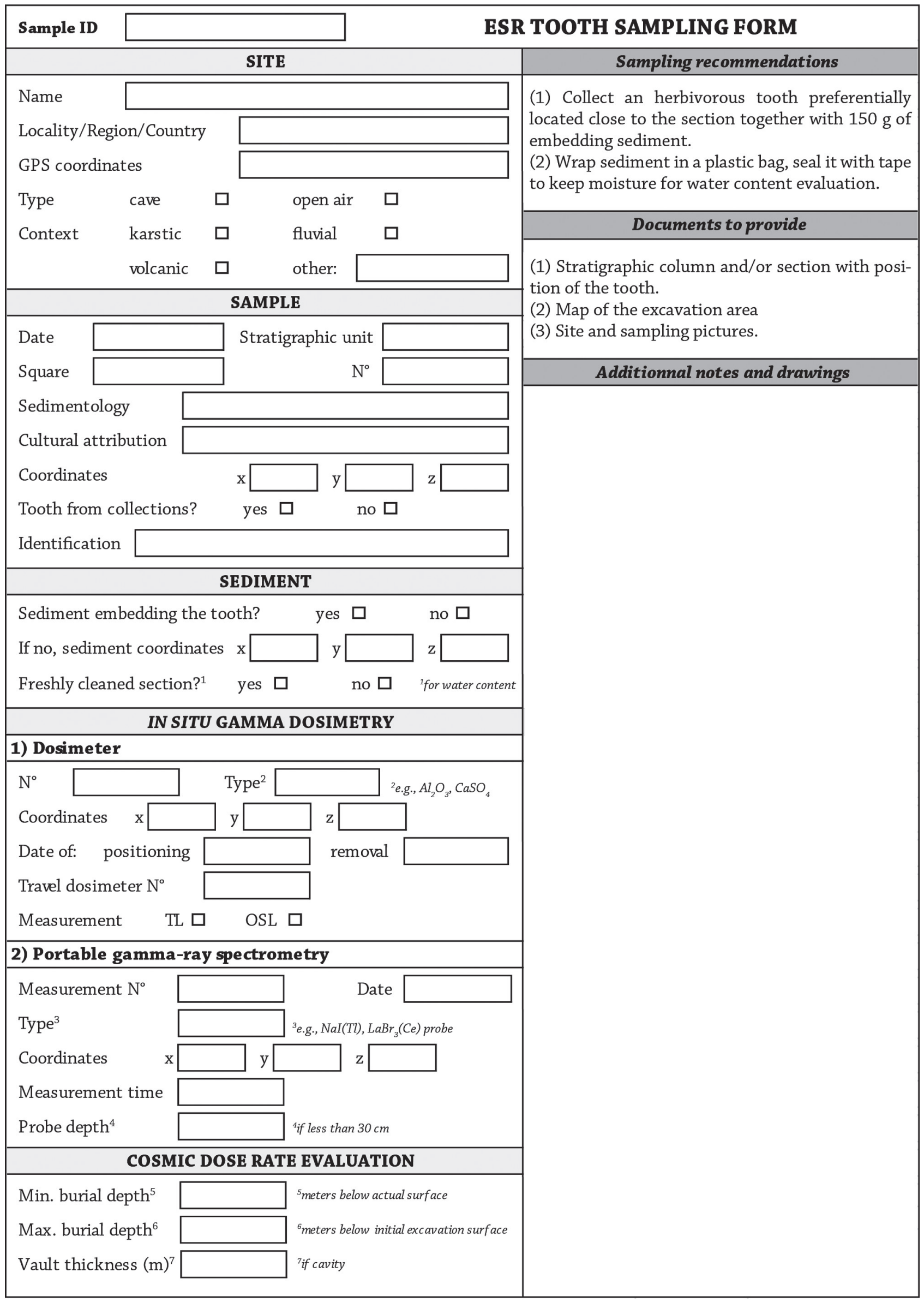

Fig. 2: Sampling form for ESR dating of fossil tooth.

Fig. 2 : Fiche d'échantillonnage pour la datation par ESR des dents fossiles. 
original position. However, because the in situ dosimetry requires owning dosimeters and/or a portable gamma spectrometer, it is generally carried out by a specialist.

Additional information and drawings related to the sampling and the dosimetry may be added to the form. For example, documents such as stratigraphic column and/or section, site plan showing the excavation area (for an archaeological site), regional maps (for fluvial terrace sequence) and pictures documenting the sampling and the site should preferentially be enclosed to provide a comprehensive overview of the sample in its surrounding environment.

\section{6 - CONCLUSION}

The lack of information regarding the sample itself and the conditions of sampling can be a major source of uncertainty, especially for a palaeodosimetric dating method such as ESR. Indeed, a tooth cannot be dated without a good knowledge of its sedimentary context, since the dose rate needs to be accurately reconstructed. By definition, field work is the first step of the ESR dating procedure, and the reliability of the age result depends on the accuracy of the data collected on site, such as the position of the tooth and its embedding sediment, the in situ dosimetry measurements and the estimation of the thickness of the overlying deposits. In order to implement ESR dating under the best possible conditions, we provided here some guidelines and designed a sampling form for non-ESR specialists intending to sample teeth, as it includes all the data necessary to record and report for an ESR age calculation. The tooth and sediment sampling can be easily performed by following the basic instructions given above and should be carried out while the excavation is still ongoing. However, the involvement of an ESR specialist in the field is highly recommended, in particular for in situ dosimetry matter.

\section{ACKNOWLEDGEMENTS}

M. Duval's research is funded by an Australian Research Council Future Fellowship Grant (FT150100215). The authors would like to thank Norbert Mercier for the review of the article.

\section{REFERENCES}

GRÜN R., 1989 - Electron spin resonance (ESR) dating. Quaternary International, 1, 65-109.

IKEYA M., 1993 - New applications of Electron Spin Resonance. World Scientific Publishing, Singapour, 500 p.

DESPRIÉE J., VOINCHET P., TISSOUX H., BAHAIN J.-J., FALGUÈRES C. \& COURCIMAULT G., 2012 - Géochronologie et Préhistoire des formations fluviatiles fossiles en Région Centre. Archea, Tours, $196 \mathrm{p}$.

DUVAL M., 2015 - Electron Spin Resonance (ESR) Dating of Fossil Tooth Enamel. In Rink W. J., Thompson J. W. (Eds), Encyclopedia of Scientific Dating Methods. Springer Netherlands, 239-246.

DUVAL M., AUBERT M., HELLSTROM J. \& GRÜN R., 2011 High resolution LA-ICP-MS mapping of $U$ and Th isotopes in an early Pleistocene equid tooth from Fuente Nueva-3 (Orce, Andalusia, Spain). Quaternary Geochronology, 6 (5), 458-467.

MERCIER N. \& FALGUÈRES C., 2007 - Field gamma dose-rate measurement with a $\mathrm{NaI}(\mathrm{Tl})$ detector: re-evaluation of the "threshold" technique. Ancient TL, 25 (1), 1-4.

PRESCOTT J.R. \& HUTTON J.T., 1994 - Cosmic ray contributions to dose rates for luminescence and ESR dating: Large depths and long-term time variations. Radiation Measurements, 23 (2-3), 497-500.

RICHARD, M., FALGUÈRES, C., PONS-BRANCHU, E., BAHAIN, J.J., VOINCHET, P., LEBON, M., VALLADAS, H., DOLO, J.M., PUAUD, S., RUE, M., DAUJEARD, C., MONCEL, M.H., RAYNAL, J.P., 2015 - Contribution of ESR/U-series dating to the chronology of late Middle Palaeolithic sites in the middle Rhône valley, southeastern France. Quaternary Geochronology 30 (part B), 529-534

VALLADAS, G., 1982 - Mesure de la dose gamma annuelle de l'environnement d'un site archéologique par un dosimètre TL. PACT, 6, $77-85$. 